\title{
Pengaruh Metode Pemberian Tugas terhadap Hasil Belajar Matematika Siswa
}

\author{
Asmedy \\ Program Studi Pendidikan Teknologi Informasi, STKIP Yapis Dompu \\ E-mail: asmedy.ainara@gmail.com
}

Article History: Received: 2021-05-12 || Revised: 2021-07-17 || Published: 2021-08-15

Sejarah Artikel : Diterima: 2021-05-12 || Direvisi: 2021-07-17 || Dipublikasi: 2021-08-15

\begin{abstract}
Giving assignments is a method that is applied in the teaching and learning process, by giving assignments to students after the teacher provides material that is knowledgeable. This study aims to determine the effect of assignment methods on mathematics learning outcomes. This type of research is a correlation eith a quantitative approach. Then population was all students of SD Negeri 16 Dompu, totaling 246 students. The sample used was 19 student in fifth grade. To obtain data, the authors used data collection techniques in the form of questionnaires/questionnaires and documentation. Data were analyzed using t-test. The t-test result obtained $t$ count of 0,425 and $t$ table of 1.740 . Obtained $t$ counth is smaller than $t$ table at an error level of $5 \%$ and $\mathrm{dk}$ of 16,2509 . Baden on the hypothesis proposed there is no effect of assignment method on mathematics learning outcomes.
\end{abstract}

Keywords: Method, Assignment, Learning Outcomes.

\begin{abstract}
Abstrak
Pemberian Tugas merupakan suatu metode yang diterapkan dalam proses belajar mengajar, dengan memberikan tugas kepada siswa setelah guru memberikan materi yang bersifat pengetahuan. Penelitian ini bertujuan untuk mengetahui pengaruh metode pemberian tugas terhadap hasil belajar matematika. Jenis penelitian ini ialah korelasi dengan pendekatan kuantitatif. Populasi ialah seluruh siswa SD Negeri 16 Dompu yang berjumlah 246 orang siswa. Sampel yang digunakan adalah siswa kelas V sebanyak 19 siswa. Untuk memperoleh data penulis menggunakan teknik pengumpulan data berupa kuesioner/angket dan dokumentasi. Data dianalisis menggunakan uji-t. Hasil uji-t diperoleh thitung sebesar 0,425 dan dan ttabel sebesar 1,740. Diperoleh thitung lebih kecil dari pada ttabel pada taraf kesalahan 5\% dan dk sebesar $16,2409 \%$. Berdasarkan hipotesis yang diajukan tidak terdapat pengaruh metode pemberian tugas terhadap hasil belajar matematika.
\end{abstract}

Kata kunci: Metode, Penilaian, Hasil Belajar.

\section{PENDAHULUAN}

Pendidikan secara sederhana dapat di artikan sebagai usaha manusia untuk membina kepribadiaan sesuai dengan nilai-nilai di dalam masyarakat dan kebudayaan. Dengan demikian, bagaimanapun sederhananya peradaban suatu masyarakat, didalamnya terjadi atau berlangsung suatu proses pendidikan.karena itulah sering dinyatakan pendidikan telah ada sepanjang peradaban umat manusia berdasarkan (Undang-undang nomor. 39 tahun 1999 pasal 12 tentang Hak Asasi Manusia), disebutkan bahwa setiap orang berhak atas perlindungan bagi pengembangan pribadinya untuk memperoleh pendidikan,mencerdaskan dirinya, dan meningkatkan kualitas hidupnya agar menjadi manusia yang beriman, bertaqwa, bertanggung jawab, berakhlak mulia, bahagia, dan sejahtera sesuai dengan hak asasi manusia. Hal tersebut memberikan gambaran bahwa pendidikan merupakan dasar yang harus di miliki oleh manusia dalam mengembangkan kepribadian dan kualitas hidupnya, Jabaran UUD 1945 tentang tujuan pendidikan nasional dituangkan dalam undang-undang No. 20 tahun 2013, Pasal menyebutkan, “ Pendidikan Nasional Berfungsi mengembangkan kemampuan dan membentuk watak serta peradaban bangsa yang martabat dalam rangka mencerdaskan kehidupan bangsa, bertujuan untuk berkembangnya potensi peserta didik agar menjadi manusia yang beriman dan bertaqwa kepada tuhan yang maha esa, berakhlak mulia, sehat, berilmu, cakap, kreatif, mandiri, dan menjadi warga negara yang demokratis serta 
bertanggung jawab. Agar tujuan pendidikan nasional dapat tercapai secara maksimal maka diperlukan proses pembelajaran yang berkualitas dalam upaya pengembangan serta perbaikan melalui inovasi pendidikan.

Belajar merupakan suatu proses yang terjadi pada diri seseorang dari tahu menjadi tahu. Seperti yang dikemukakan oleh Suyono (2011: 165) belajar adalah suatu upaya pembelajaran untuk mengembangkan seluruh kepribadian, baik fisik maupun psikis. Belajar juga yang di maksudkan untuk mengembangkan seluruh aspek intelegensi sehingga anak didik menjadi manusia yang utuh, cerdas secara intelegensi, cerdas secara emosional, cerdas secara psikomotor, dan memiliki keterampilan yang berguna untuk kehidupanya, Belajar adalah hal yang pokok melekat pada diri peserta didik mulai dari tingkat Sekolah Dasar (SD) Sampai dengan tingkat Perguruan Tinggi. Semakin tinggi tingkat pendidikan yang ditempuh oleh peserta didik tersebut, maka makin tinggi pula beban belajar yang di tempuh peserta didik. Disini perlu adanya kesadaran setiap peserta akan arti penting dan hasil yang diperoleh dari belajar. Hasil belajar yang baik akan diperoleh jika berusaha secara maksimal dan yang digunakan oleh peserta didik itu tepat.

Belajar meupakan serangkaian kegiatan jiwa raga untuk memperoleh suatu perubahan tingkah laku sebagai hasil dari pengalaman individu dalam interaksi dengan lingkungannya yang menyangkut kognitif, afektif, dan psikomotor. Sehingga kebisaan belajara yang dilakukan peserta didik itu akan mempengaruhi hasil yang dicapai. Beberapa faktor yang mempengaruhi belajar ada dua yaitu faktor intern dan faktor ekstern. Faktor internal itu sendiri meliputi faktor jasmanih, faktor psikologis dan faktor kelelahan. Sedangkan yang faktor eksternal itu sendiri meliputi faktor keluarga, faktor sekolah dan faktor masyarakat, Setiap peserta didik itu mempunyai karakteristik yang beragam. Salah satu peserta didik dapat menempuh kegiatan belajarnya secara lancar dan berhasil tanpa mengalami berbagai kesulitan, sedangkan tidak sedikit pula ada peserta didik yang dalam belajarnya mengalami kesulitan belajar. Kesulitan belajar siswa ditunjukan oleh hambatanhambatan tertentu untuk mencapai hasil belajar dan dapat bersifat psikologis, sosiologis, maupun fisiologis sehingga pada akhirnya prestasi belajar yang dicapai dibawah semestinya.

Setelah munculnya wabah Corona virus disease (Covid-19) di belahan bumi. Sistem pendidikan pun mulai mencari suatu inovasi untuk proses kegiatan belajar mengajar. Terlebih adanya surat edaran No. 4 Tahun 2020 dari Menteri Pendidikan harus jaga jarak dan seluruh penyampaian materi akan disampaikan di rumah masing-masing, Setiap institusi pun dituntut untuk memberikan inovasi terbaru untuk membentuk proses pembelajaran yang sangat efektif ini. Sayangnya tak semua institusi pendidikan rupanya paham betul mengenai inovasi terbaru yang harus dipakai untuk melakukan pembelajaran selama pandemi Covid-19. Kebanyakan dari sekolah masih belum bisa menyesuaikan karena kendala sarana prasarana, Mengingat adanya perkembangan pandemi Covid19 dan ditambah lagi keterbatasan waktu dalam proses belajar dan mengajar disekolah, maka perlu sekali seorang guru memberikan tugas-tugas untuk dikerjakan di rumah. Pemberian tugas ini merupakan salah satu cara yang efektif yang dilakukan oleh guru dalam proses belajar mengajar, yaitu suatu pengajaran yang dilakukan dengan memberikan tugas kepada peserta didik, karena pada dasarnya pemberian tugas menuntut kreativitas dan aktivitas mereka, diantara keuntungan pemberian tugas oleh guru ialah agar pengetahuan yang telah dipelajari oleh peserta didik dapat dikuasai dan tersimpan lama dalam ingatan mereka, Selain itu pemberian tugas dapat memupuk rasa tanggung jawab dan harga diri anak, disamping membiasakan diri untuk mengisi waktu luangnya dengan hal yang lebih positif dan berguna. Oleh karena itu, pemberian tugas harus sesuai dengan karakteristik siswa, materi, kondisi lingkungan dimana pengajaran berlangsung.

Seiring dengan perkembangan Covid-19 di dalam dunia pendidikan. Beberapa ahli sudah menemukan bermacam-macam metode pembelajaran yang efektif selama pandemi. Dari beberapa metode yang cocok selama pandemi ini, terdapat salah satu metode yang efektif digunakan dalam pemberian tugas, Metode pemberian tugas adalah mengajar yang ditandai dengan adanya kegiatan perencanaan antara guru dengan siswa tentang suatu masalah yang harus diselesaikan dalam jangka waktu yang telah disepakati bersama. Hal tersebut sesuai dengan pendapat Oemar Hamalik bahwa kegiatan belajar dengan metode tugas adalah kegiatan belajar yang direncanakan guru yang berlainan dengan pengajaran di sekolah, tetapi dikerjakan di luar sekolah (Oemar Hamalik, 1984:74). Berdasarkan hasil observasi awal, tanggal 28 Agustus 2020 di SD Negeri 16 Dompu, 
dengan guru kelas yang berinisial $\mathrm{H}$, mengemukakan bahwa dalam pemberian tugas pekerjaan rumah selama masa pandemi Covid-19 ada yang giat ada pula yang bermalas-malasan dalam mengerjakan dan mengumpulkan tugas yang diberikan oleh guru. Cara guru ini menambah daya tarik siswa dengan menggunakan spidol berwarna ketika mengajar dan bermain sambil belajar, namun siswa masih banyak yang kurang tertarik dengan pembelajaran matematika. Pada saat pembelajaran, sebagian siswa enggan memperhatikan apa yang di jelaskan. Siswa juga kurang memperhatikan pelajaran dan hanya mengobrol sendiri dengan teman, sehingga siswa dalam mengangkap materi kurang maksimal. Guru juga menuturkan banyak siswa yang kurang mengerti dalam penyelesain soal matematika, sehingga banyak yang siswa merasa bosan ketika pembelajaran matematika berlangsung. Guru menambahkan bahwa beberapa siswa terkadang mengeluhkan bahwa mereka menemui kesulitan menemukan cara menjawab soal-soal yang diberikan, Berdasarkan latarbelakang masalah tersebut, maka peneliti mengambil judul“Pengaruh Metode Pemberian Tugas terhadap Hasil Belajar Matematika".

\section{METODE PENELITIAN}

Korelasi/hubungan dengan pendekatan kuantitatif. Artinya peneliti mengumpulkan data dengan mengadakan survey lapangan kemudian dicari hubungan antar variabel. Dilihat dari jenisnya, Penelitian yang peneliti angkat ini termasuk penelitian korelasional yang sifatnya melukiskan hubungan saling mempengaruhi hubungan yang terdapat antar variabel bebas berupa metode pemberian tugas $(\mathrm{X})$ dengan variabel terikat yaitu hasil belajar siswa (Y), data berupa populasi siswa SD Negeri 16 Dompu jumlah keseluruhan siswa dari kelas 1-6 sebanyak 246 siswa. Dan penelitian ini peneliti mengambil kelas V sabagai sampel dengan jumlah siswa 19 orang.

\section{HASIL DAN PEMBAHASAN}

\section{A. Hasil Penelitian}

\section{Data Angket}

Angket yang digunakan berupa angket tertutup dengan jumlah pertyataan sebanyak 15 nomor, diketahu bahwa nilai angket Diketahui hasil belajar dari metode pemberian tugas siswa kelas $\mathrm{V}$ memperoleh skor 75 sebanyak 3 orang dengan inisial nama (FA) (MDR) (MQA), siswa yang memperoleh skor 72 sebanyak 2 orang dengan inisial nama (DKA) (DP), siswa yang memperoleh skor 71 sebanyak 1 orang dengan ini sial nama (HF), siswa yang memperoleh skor 69 sebanyak 1 orang dengan ini sial nama (HR), siswa yang memperoleh skor 68 sebanyak 1 orang dengan ini sial nama (MRR), siswa yang memperoleh skor 67 sebanyak 1 orang dengan ini sial nama (SB), siswa yang memperoleh skor 66 sebanyak 1 orang dengan ini sial nama (MA), siswa yang memperoleh skor 65 sebanyak 2 orang dengan ini sial nama (AI) (SK), siswa yang memperoleh skor 64 sebanyak 2 orang dengan ini sial nama (F) (I), siswa yang memperoleh skor 63 sebanyak 1 orang dengan ini sial nama (RA), siswa yang memperoleh skor 61 sebanyak 2 orang dengan ini sial nama (AS) (MIF), siswa yang memperoleh skor 60 sebanyak 1 orang dengan ini sial nama $(\mathrm{MN})$, siswa yang memperoleh skor 51 sebanyak 1 orang dengan ini sial nama (MJ). Hasil angket memperoleh jumlah 1.264

\section{Data Hasil belajar Semester Ganjil}

Berdasarkan hasil belajar dari pembelajaran online/daring siswa kelas V memperoleh nilai 90 sebanyak 8 orang dengan inisial nama siswa (AI) (DP) (MIF) (MDR) (MA) (MQA) (MRR) (MN), siswa yang memperoleh nilai 80 sebanyak 5 orang siswa dengan kode nama (DKA) (FA) (I) (RA) (SK), siswa yang memperoleh nilai 70 sebanyak 4 orang dengan inisial nama (F) (HR) (HF) (SB), siswa yang memperoleh nilai 60 sebanyak 2 orang dengan inisial nama (MJ) (AS), Hasil nilai tes diperoleh jumlah keseluruhan nilai 1.520 kemudian dibagi dengan jumlah kelas sebanyak 19 orang siswa maka nilai rata-rata yang didapatkan adalah 80, dapat diketahui bahwa jumlah skor variabel bebas $(\mathrm{X})$ yaitu sebesar 1.264, jumlah skor variabel terikat $(\mathrm{Y})$ yaitu sebesar 1.520, jumlah kuadrat skor variabel bebas (X) yaitu sebesar 84.768, jumlah kuadrat skor variabel terikat (Y) yaitu sebesar 123.600, dan jumlah perkalian skor variabel bebas dan terikat yaitu sebesar 101.590.

3. Analisis koefisien korelasi

Dari hasil angket metode pemberian tugas, diketahui bahwa jumlah skor metode pemberian tugas siswa secara keseluruhan yang berjumlah 19 siswa 1.262 dengan rata-rata 66,526. Hasil 
rata-rata metode pemberian tugas termasuk dalam kategori sangat baik. Sedangkan hasil belajar di ketahui bahwa jumlah skor hasil belajar siswa secara keseluruhan yang berjumlah 19 siswa sebesar 1.520 dengan rata-rata 80 . Hasil rata-rata hasil belajar siswa termasuk dalam kategori sangat baik, Dari perhitungan statistik dapat diketahui bahwa antara variabel X (metode pemberian tugas) dengan variabel Y (hasil belajar siswa berupa nilai ulangan) bertanda positif dengan memperhatikan besarnya ${ }^{r_{X Y}}$ yang diperoleh sebesar 0,403. Apabila hasil tersebut diinterprestasikan dengan mencocokan angka indeks korelasi berdasarkan ketentuan yang berlaku, angka 0,403 berada diantara 0,40-0,599 berarti ada korelasi antara variabel X dengan variabel $Y$ yang termasuk dalam kategori sedang, Berdasarkan hasil perhitungan menunjukan bahwa nilai korelasi sebesar 0,403 menunjukan bahwa korelasi antara Variabel X dan Y sangat bagus.

4. Analisis Koefisien Determinasi

Setelah menghitung nilai koefisien korelasi, dilanjutkan dengan menghitung analisis koefisien determinasi dengan rumus:

$$
\begin{aligned}
\mathrm{Kd} & =r^{2} \times 100 \% \\
\mathrm{Kd} & =0,4032 \times 100 \% \\
& =0,162409 \times 100 \% \\
\mathrm{Kd} & =16,2409 \%
\end{aligned}
$$

Berdasarkan hasil nilai analisis koefisien determinasi dengan nilai yang dihasilkan 16,2409\% jadi dari hasil menunjuhkan bahwa pengaruh variable X dan variabel Y sebesar 16,2409\%.

5. Pengujian Hipotesis Penelitian (Uji T)

Untuk membuktikan hipotesis (Ha) yang berbunyi "terdapat pengaruh yang positif dan signifikan antara pengaruh metode pemberian tugas terhadap hasil belajar matematika siswa", dengan demikian thitung lebih kecil dari ttabel $\left({ }^{0,425}<1,740\right)$ pada taraf signifikan $5 \%$ ini berarti signifikan maka Ha ditolak dan Ho diterima artinya tidak ada Pengaruh Metode Pemberian Tugas Terhadap Hasil Belajar Matematika Siswa SD Negeri 16 Dompu Tahun Pembelajaran 2020/2021, Karena persyaratan analisis telah diuji hipotesis. Dari hasil analisis dengan menggunakan rumus ttest diperoleh koefisien thitung $={ }^{0,425}$ kemudian hasil analisis ini dikonsultasikan dengan ttabel $\mathrm{N}=19$ dan 17 diperoleh harga ttabel 1,740 karena thitung < ttabel, maka sesuai dengan persyaratan pengujian hipotesis maka Ha diterima dan Ho ditolak artinya tidak ada Pengaruh Metode Pemberian Tugas Terhadap Hasil Belajar Matematika Siswa SD Negeri 16 Dompu Tahun Pembelajaran 2020/2021.

\section{B. Pembahasan}

1. Metode Pemberian Tugas

Metode pemberian merupakan salah satu tindakan yang diambil oleh sekolah untuk terus melaksakan pembelajaran pada masa covid-19, untuk menghindari dari penyebaran virus covid-19 tersebut. Peneliti mengambil 19 siswa kelas V untuk dijadikan sempel penelitian Untuk mengetahui tingkat pengaruh peneliti memberikan tes, dan angket kepada 24 orang siswa. Tes ini dibuat oleh peneliti Sebelum angket disebarkan peneliti memberikan pengetahuan tatacara untuk mengisi angket tesebut begitu pilah, dalam angket tersebut peneliti memberikan bobot nilai $S S=5 \mathrm{~S}=4 \mathrm{KS}=3$ TS=3 STS=1 pada masing-masing pernyataan sehingga terdapat hasil 1.264 kemudian dibagi dengan jumlah kelas sebanyak 19 orang siswa maka nilai rata-rata yang didapatkan adalah 66,526 dan jumlah nilai angketnya sebanyak 1.520. kemudian dibagi dengan jumlah kelas 19 orang maka nilai rata-rata yang didapatkan adalah 80 .

2. Hasil Belajar Siswa

Hasil belajar dapat ditingkatkan melalui usaha sadar yang dilakukan secara sistematis mengarah kepada perubahan yang positif yang kemudian disebut dengan proses pembelajaran, sesuai dengan teori yang dikemukakan oleh Wahidmurni, (2010: 18) menyatakan bahwa "seseorang dapat dikatakan telah berhasil dalam belajar jika ia mampu menunjukkan adanya perubahan dalam dirinya. Perubahan-perubahan tersebut diantaranya dari segi kemampuan berpikirnya, keterampilannya, atau sikapnya terhadap suatu objek", Berdasarkan data hasil penyebaran angket 
(variabel X) tentang pengaruh metode pemberian tugas diperoleh skor total sebesar 1.264 dengan skor rata-rata yaitu 66,526, skor tertinggi dari 19 siswa adalah 75 dan skor terendahnya adalah 51 . Data tersebut menunjukan bahwa ada pengaruh yang kuat antara metode pemberian tugas terhadap hasil belajar matematika siswa kelas V SD Negeri 16 Dompu tahun pembelajaran $2020 / 2021$.

Sedangkan data hasil belajar matematika siswa kelas V SD Negeri 16 Dompu (variabel Y), diperoleh skor total 1.520 dengan skor rata-rata 80 skor tertinggi yang diperoleh dari 19 siswa adalah 90 dan skor terendahnya adalah 60. Data tersebut menunjukan bahwa nilai hasil belajar matematika siswa kelas V SD Negeri 16 Dompu tahun pembelajaran 2020/2021 tergolong sangat baik dan jika dikaitkan dengan data penyebaran angket tentang metode pemberian tugas maka kedua data tersebut menunjukan tidak ada pengaruh yang signifikan.

3. Pengaruh Metode Pemberian Tugas Terhadap Hasil Belajar Matematika Siswa

Metode pemberian tugas sangatlah terpengaruh bagi siswa, baik dalam menghadapi proses pembelajaran, ulangan harian, ujian, dan kesulitan dalam memahami materi yang telah disampaikan, dengan adanya motivasi belajar siswa dapat memberikan semangat belajar siswa yang tinggi dan tidak di batasi pada waktu, Seberapa besar kontribusi (sumbangan) variabel X dalam mempengaruhi variabel $Y$ dapat dilihat dari nilai koefisien determinasi. Dari hasil hitung didapatkan nilai koefisien determinasi sebesar 16,2409\% dengan kata lain, pelaksanaan metode pemberian tugas dalam proses pembelajaran memberikan kontribusi atau mempengaruhi secara positif hasil belajar siswa sebesar 16,2409\%

Hasil Belajar siswa kelas V SD Negeri 16 Dompu sudah cukup memenuhi syarat dalam penilaian, hanya beberapa siswa yang masih kuarang nilai hasil belajar matematika dan guru SD Negeri 16 Dompu akan terus berusaha untuk mengembangkan metode pembelajaran yang dapat memotivasi siswa untuk selalu bersemangat dalam belajar sehingga mencapai hasil belajar yang bagus.

\section{SIMPULAN DAN SARAN}

\section{A. Simpulan}

Berdasarkan penelitian yang telah dilakukan tentang Pengaruh Metode Pemberian Tugas Terhadap Hasil Belajar Matematika Siswa SD Negeri 16 Dompu Tahun Pembelajaran 2020/2021 maka diperoleh, nilai $r$ yang diperoleh dalam penyelidikan adalah 0,403 sedangkan nilai $r$ tabel dengan taraf signifikan 5\% adalah 1,740 dan koefisien determinasi sebesar 16,2409\% dipengaruhi oleh variabel lain yang tidak diteliti dan nilai thitung sebesar ${ }^{0,425}$ dan ttabel sebesar 1,740 sehingga hipotesis yang diajukan ditolak, maka dapat disimpulkan bahwa "tidak terdapat Pengaruh Metode Pemberian Tugas Terhadap Hasil Belajar Matematika Siswa Kelas V SD Negeri 16 Dompu Tahun Pembelajaran 2020/2021.

\section{B. Saran}

Berdasrkan hasil penelitian dan pembahasan, saran yang diperlukan pada penelitian ini diantaranya: (1) Bagi Guru, Dari hasil penelitian ini diharapkan dapat bermanfaat untuk bahan masukan, bahwa dengan memberikan motifasi terus menrus terhadap emosional siswa, maka akan memberikan salah satu faktor yang akan membatu siswa untuk semangat belajar. (2) Bagi siswa, Hasil penelitiini diharapkan dapat terus meningkatkan motifasi belajar siswa dalam proses pembelajaran, (3) Peneliti berikutnya, Hasil penelitian ini dapat dijadikan bahan pembelajaran bagi peneliti sendiri, karena dengan mendorong dan memberi motifasi terus terhadap emosional siswa, maka akan dampat mempengaruhi dari hasil belajar siswa, dan akan memberikan motifasi tersendiri bagi siswa dalam proses pembelajaran.

\section{DAFTAR RUJUKAN}

Ahmad Susanto. (2015). Teori Belajar Dan Pembelajaran Disekolah Dasar. .Jakarta: Prenada Media.

Akmal Hawi, Kompetensi Guru PAI, (Jakarta: PT. Raja Grafindo Persada, 2013)

Arikunto, S. (2009). Prosedur Penelitian Suatu Pendekatan Praktik. Edisi Revisi 6. Jakarta : Rineka Bandung : Alfabeta. 
Arikunto, S. 2010. Prosedur Penelitian Suatu Pendekatan Praktik. Jakarta: Rineka Cipta

Aswan, Zain, Bahri syamsul, Djamarah. (2006), Strategi Belajar Mengajar. Jakarta: Penerbit PT. Rineka Cipta

Hamalik, Oemar.(1983). Metode Belajar dan Kesulitan-kesulitan Belajar. Bandung: Tarsito

Hamiyah, N Dan M. Jauhar. (2014).Strategi Belajar-Mengajar di Kelas. Jakarta: Prestasi Pustaka.

Hamzah, Ali. (2014). Evaluasi Pembelajaran Matematika. Jakarta: Rajawali Pers.

JIIP, R. (2019). Representasi Diferensiasi Sosial pada Novel Kambing \& Hujan Karya Mahfud Ikhwan dan Relevansinya dalam Pembelajaran Sosiologi Sastra di Perguruan Tinggi: Representasi Diferensiasi Sosial pada Sebuah Novel. JIIP - Jurnal Ilmiah Ilmu Pendidikan, 2(1), 166-175. Retrieved from http://jiip.stkipyapisdompu.ac.id/jiip/index.php/JIIP/article/view/38

Kemendikbud. (2020). Surat Edaran No. 4 Tahun 2020 Tentang Pelaksanaan dalam Masa Darurat PenyebaranCORONA VIRUS DISEASASE (Covid-19).

Kementrian Pendidikan dan Kebudayaan. 2020. Metode Pembelajaran Model Luring Sistem Pertahanan Tubuh dan Implikasinya terhadap Penyebaran Covid19(online),(https://guruberbagi.kemendikbud.go.id/artikel/metode-pembelajaran-modeluring-sistem-pertahanan-tubuh-dan-implikasinya-terhadap-penyebaran-covid19/diakses 23 september 2020)

Mulyani Sumantri, dkk. (2001). Strategi Belajar Mengajar. Bandung: CV Maulana

Taufik, Erwin, \& Husnul Khatimah. (2020). Model Pembelajaran CIRC pada Mata Kuliah Apresiasi Sastra "Mantra Mbojo" untuk Meningkatkan Kreativitas Mahasiswa. Ainara Journal (Jurnal Penelitian Dan PKM Bidang Ilmu Pendidikan), 1(2), 62-70. https://doi.org/10.1234567/ainarajournal.v1i2.15

Taufik, Erwin, \& Husnul Khatimah. (2020). Pengembangan Perangkat Pembelajaran Model CIRC pada Mata Kuliah Apresiasi Sastra "Mantra Mbojo" untuk Melatih Kemampuan Berpikir Kreatif Mahasiswa.JIIP - Jurnal Ilmiah Ilmu Pendidikan,3(3), 635-641. Retrieved from http://jiip.stkipyapisdompu.ac.id/jiip/index.php/JIIP/article/view/171

Taufik. (2020). Ambiguitas dalam Humor Karmina/Pantun Kilat Suku Mbojo Sebagai Pelesetan Makna: Taufik, Eka Yulianti. JIIP - Jurnal Ilmiah Ilmu Pendidikan,3(1), 375-380. Retrieved from http://jiip.stkipyapisdompu.ac.id/jiip/index.php/JIIP/article/view/103 